\title{
Investigating the Association between Residual State Ownership and Privatized Firm Efficiency
}

\author{
Manh Hoang NGUYEN ${ }^{1}$, Quy Thi VO ${ }^{2}$
}

Received: March 02, 2020 Revised: March 15, 2020 Accepted: April 03, 2020

\begin{abstract}
This paper examines empirically the net impact of residual state ownership on privatized firm efficiency in the transitional context of Vietnam. Vietnamese privatization has its own characteristics. Instead of mass and full privatization, Vietnam has chosen a partial and gradual path. Thus, it is important to assess the net impact of residual state ownership on privatized firms during the post-privatization period. This study employs stochastic frontier analysis to investigate the association between residual state ownership and the efficiency of privatized firms, using a sample of all privatized firms that are listed on the Vietnamese stock exchanges over the period from 2007 to 2017. Also, two-stage least squares regression is incorporated into the model to deal with potential endogeneity issues. Our study provides evidence that state ownership should not be considered as a pure source of agency problems. Indeed, the net impact of residual state ownership on privatized firm efficiency is non-monotonic, and the relationship between residual state ownership and privatized firm efficiency is under an inverted U-shape. A moderate level (less than 50\%) of residual state ownership might be beneficial to privatized firm efficiency whereas too much state ownership is detrimental to the efficiency of privatized firms.
\end{abstract}

Keywords : Vietnam, Privatization, State Ownership, Firm Efficiency, Firm Performance

JEL Classification Code: G30, L32, L33, P31

\section{Introduction}

Vietnam initiated the economic reform in 1986 to transform its command economy into a market-based economy. As part of the economic reform, the government considered privatization as a vital strategy to restructure and enhance the efficiency of state-owned enterprises

\footnotetext{
${ }^{1}$ First Author and Corresponding Author. [1] School of Business, International University, Vietnam National University, Ho Chi Minh City, Vietnam [Postal Address: Quarter 6, Linh Trung Ward, Thu Duc District, Ho Chi Minh City, 721400, Vietnam]/ [2] Swinburne Business School, Swinburne University of Technology, Melbourne, Australia [Postal Address: John Street, Hawthorn, Victoria 3122, Australia] Email: manhnguyen@swin.edu.au

${ }^{2}$ School of Business, International University, Vietnam National University, Ho Chi Minh City, Vietnam [Postal Address: Quarter 6, Linh Trung Ward, Thu Duc District, Ho Chi Minh City, Vietnam] Email: vtquy@hcmiu.edu.vn
}

(c) Copyright: The Author(s)

This is an Open Access article distributed under the terms of the Creative Commons Attribution Non-Commercial License (http://Creativecommons.org/licenses/by-nc/4.0/) which permits unrestricted noncommercial use, distribution, and reproduction in any medium, provided the original work is properly cited.
(SOEs). Privatization is carried out with primary objectives to mobilise capital from the private sector and to improve worker incentives by turning them into firm's shareholders. The Vietnamese government has privatized more than 4,500 SOEs from 1992 to now. The privatization has been recognised to have a positive impact on Vietnam's fully state-owned enterprises (Loc, Lanjouw, \& Lensink, 2006; Ngo, Nonneman, \& Jorissen, 2015). Nevertheless, some goals have not been achieved, including the goal of reducing state capital in SOEs and attracting private investment into privatized SOEs. Thus, the state sector still contributes to one-third of the country's gross domestic product (GDP).

The privatization literature indicates that privatization is beneficial to fully state-owned firms in most cases (Megginson, 2017). However, research on the net impact of residual state ownership among privatized firms provides heterogeneous results, both detrimental and beneficial effects of state ownership (Boubakri, El Ghoul, Guedhami, \& Megginson, 2018). This motivates us to study the efficiency of privatized firms across different levels of residual state ownership by utilising the stochastic frontier analysis (SFA) technique. We believe that SFA may provide a more accurate analysis of the net impact of residual state ownership, since 
SFA is designed to capture both the actual inefficiency and the random effects.

Our empirical results suggest that the impact of residual state ownership on privatized firm efficiency is non-linear. At a moderate level (less than 50\%), state ownership may enhance the efficiency of privatized firms; however, as state ownership becomes dominant, the net impact of residual state ownership is negative and significantly detrimental to the privatized firm efficiency. These findings could be clarified via the light of agency theory and soft budget constraint theory.

This paper is structured into six sections. Section 2 covers the related literature. Section 3 presents the research methodology. Sections 4 discusses the empirical results and robustness test. Sections 5 and 6 provide the discussion and conclusion.

\section{Literature Review}

In the global context, there is overwhelming evidence that privatization improves SOEs' performance. The majority of studies on this side implement pre- and post-privatization comparisons and find that privatization significantly increases the profitability and efficiency of SOEs (Boubakri, Cosset, \& Guedhami, 2005; Megginson, Nash, \& Randenborgh, 1994; Souza, Megginson, \& Nash, 2005; Souza \& Megginson, 1999). However, the impact of the remaining state ownership among privatized firms is still a controversial issue (Boubakri, El Ghoul, Guedhami, \& Megginson, 2018).

From the view of agency theory of Jensen and Meckling (1976), the opponents of state ownership argue that the remaining state ownership may lead to governmental intervention in the day-to-day business of privatized firms. The state (via its control) may divert firms' resources to pursue social or non-economic objectives that may contradict the pure wealth maximisation objectives of minority shareholders and negatively affect firm performance (Bennedsen, 2000; Boycko, Shleifer, \& Vishny, 1996; Laffont \& Tirole, 1991). The incentive and contracting problems might create inefficiencies as a result of public ownership (Sheshinski \& López-Calva, 2003). Liu, Wang, Zhang, and Zhang (2012) mentioned that government intervention possibly distorts the compensation-performance sensitivity of executives and increases compensation stickiness, which, as a result, leads to more executive perks in SOEs. However, proponents of state ownership argue that the state has ultimately high incentive to maximise the value of state assets and may act as a monitor (via its specialised agencies) to assure the efficiency of the management team and to prevent other block holders from conducting expropriation activities. In nowadays corporate context, the ownership of shareholders has become increasingly diverse and spread out; hence, it is unlikely that individual shareholders could effectively enforce their property rights and monitor managers' behavior.
Therefore, state owner in these cases may act as a block holder to enforce "monitoring" role. In comparison to other shareholders, the state has higher capability to monitor SOEs since there are often one or few agencies (e.g. line ministries, government auditing board or SOE supervisory agency) simultaneously in charge of monitoring the efficiency of SOEs (Chang, 2007; Tian \& Estrin, 2008).

From the perspective of soft budget constraint issue, which was first characterised by Kornai (1986), supporters of state ownership argue that the state indeed has an incentive to enhance the efficiency of privatized firms to obtain tax benefits and maximise the value of state investments. Thus, the state may apply favourable instruments such as preferential regulations, favourable taxation, credit and even subsidies to support firms with high levels of state ownership (Shleifer \& Vishny, 1998). To some extent, the soft budget constraint may benefit SOEs by lowering their business risks and costs of capital which possibly result in better firm performance (Haider, Liu, Wang, \& Zhang, 2018). However, on the opposite side, the opponents of state ownership demonstrate that soft budget constraint may lead to over-investment behavior and also reduce the incentive of managers to uphold the efficiency of SOEs due to the high probability of being bailed out despite making serious losses. This may lead to a negative association between residual state ownership and firm performance in the long-run ( $\mathrm{Li}$, Yue, \& Zhao, 2009).

From theoretical views, it is plausible that the impact of residual state ownership is not universally beneficial or detrimental, instead the net impact of residual state ownership may change in accordance with the different levels of residual state ownership in privatized firms as a result of counteractive forces.s. benefits of the privatization process in Vietnam figured out that privatized firms outperform fully SOEs. (Loc, Lanjouw, \& Lensink, 2006; Ngo, Nonneman, \& Jorissen, 2015). The improvement of privatized firms' performance could be explained by the enhancement of monitoring mechanisms since non-state parties, such as institutional shareholders and foreign shareholders, can enforce supervision activities. The positive outcome may also result from the conversion of SOE's managers and employees into privatized firms' shareholders, and then align their interests with privatized firm's performance. However, the evidence on the net impact of residual state ownership on privatized firm performance is quite mixed in the Vietnamese context (Hoang, Nguyen, \& Hu, 2017; Le, Pieri, \& Zaninotto, 2019; Ngo, Nonneman, \& Jorissen, 2014; Phung \& Mishra, 2016; Vo, Swierczek, \& Nguyen, 2013). Due to these inconsistent results, we attempt to evaluate the net impact of residual state ownership in privatized firms by testing the following:

Hypothesis: Residual state ownership has a nonmonotonic impact on privatized firm efficiency. 


\section{Research Methodology}

\subsection{Research Methods}

Most previous studies on privatization performance in Vietnam have utilised the ordinary least squares (OLS) technique to assess the impact of residual state ownership on privatized firm performance. Unlike these studies, our study uses the stochastic frontier analysis (SFA), which was developed by Aigner, Lovell, and Schmidt (1977), to investigate the net impact of residual state ownership since SFA can classify firm inefficiency into actual inefficiency and random elements that are beyond the control of management of the firm (Mohamed, 2020; Nguyen \& Swanson, 2009). Moreover, SFA has become popular as an optimal econometric technique for efficiency and productivity measurements due to its internal consistency, easy implementation and close to the concept of agency costs (Greene, 2012; Kumbhakar, Ortega-Argilés, Potters, Vivarelli, \& Voigt, 2012; Manzur Quader \& Dietrich, 2014).

Using SFA can provide an econometric estimation of the optimal value function or frontier function by varying firm characteristics. Every point lying on the frontier represents the maximum value that a firm can achieve given its fundamental characteristics whereas any firm that deviates from the frontier is perceived as inefficient. A larger deviation from the frontier is associated with higher level of inefficiency. SFA technique is also able to decompose the inefficiency into actual inefficiency and random effects under the assumption that the inefficiencies follow an asymmetric distribution whereas random errors or white noise follow a standard normal distribution.

Formally, the basic SFA model can be written as follows (see e.g. Coelli, Rao, O’Donnell, and Battese (2005)):

$$
Y_{i t}=X_{i t} \beta+\varepsilon_{i t}
$$

where $Y_{i t}$ is the log of output of the firm given the input vector $X_{i t} ; \beta$ is the parameter estimate vector; $i=1, \ldots, N$ indexes the firms and $t=1, \ldots, T$ indexes the years.

Additionally, the error term is composed of

$$
\varepsilon_{i t}=v_{i t}-u_{i t}
$$

where $v_{i t}$ is the standard two-sided white noise error that is normally distributed as $N(0,) . u_{i t}$ is the systematic inefficiency and is assumed to follow a one-sided error term (e.g. a half-normal distribution with $N\left(0^{+}\right.$,). Additionally, $\operatorname{cov}\left(u_{i,}, v_{i i}\right)$ is often assumed to be 0 and let $\sigma^{2}=+$. By assumption, this $u_{i t}$ measures the inefficiency of firms and can be related to the factors explaining the inefficiency. In the case that $u_{i t}=0$ for all $i$ and $t$, the estimates from SFA are similar to those from the OLS.
There is a large literature on the extension of the above basic model but in order to evaluate the impact of residual state ownership on the efficiency of privatized firms, we use a very popular extension of the basic model proposed by Battese and Coelli (1995) in which $u_{i t}$ is assumed to be obtained by truncating at zero of $N\left(m_{i p}\right)$ and is written as follows:

$$
u_{i t}=Z_{i t} \delta+\mathrm{w}_{i t}
$$

where $Z_{i t}$ is a set of environmental variables that may affect the inefficiency of the firms, and $w_{i t}$ is defined by the truncation of the normal distribution $N\left(0, \sigma^{2}\right)$ such that the point of truncation is $-Z_{i t} \delta$, i.e., $w_{i t} \geq-Z_{i t} \delta$ where $\delta$ is a vector of unknown coefficients to be estimated. The maximum likelihood method is utilised to simultaneously estimate the parameters of the stochastic frontier and the model for the technical inefficiency effect.

\subsection{Model Specification}

We follow the idea of Manzur Quader and Dietrich (2014) to measure firm efficiency from both a long-term perspective and a short-term perspective. The long-term efficiency concentrates on the value maximisation over the longer-term horizon or wealth, whereas the short-term efficiency is based on the traditional approach that merely focuses on maximising profits.

In our study, firm's market value is used as a criterion for the long-run efficiency. From this perspective, the long-term efficiency of a privatized firm is measured by the ability of that firm to maximise the market value given its fundamental characteristics. The higher that market value is, the more efficient the firm is in maximising value for its shareholders. Additionally, a high market value reflects the potential growth prospects and sustainable business performance over the long-term perspective.

Under another scenario, earnings before tax is utilised to measure the short-term efficiency of privatized firms. Using earnings before tax as a criterion for short-term efficiency possibly removes the effect of favourable corporate income tax policies granted to privatized firms by the government. The short-term efficiency is measured by the ability of a privatized firm to maximise its profits before tax. Higher short-term efficiency is reflected by higher profits that a privatized firm can achieve given the amount of resources it utilises.

Some previous studies used firm financial characteristics as input and market value or profits as output for SFA model (ManzurQuader \& Dietrich, 2014; Nguyen \& Swanson, 2009). Following these ideas, to construct a theoretical benchmark value that a firm can potentially achieve, this study considers to control for five fundamental characteristics, including firm size measured by total assets, debt to assets ratio, equity to assets ratio, industry fixed effects and year fixed effects. 
Thus, we can obtain the following empirical models.

Market value frontier:

Ln(Market value $)_{i t}=\beta_{0}+\beta_{1}$ Ln(Assets $)_{i t}+\beta_{2}$ Debt to Assets $_{i t}+\beta_{3}$ Equity to Assets $_{i t}+$ Industry dummies + Year dummies $+v_{i t}-u_{i t}$

Profit frontier:

Ln(Earnings before tax $)_{i t}=\beta_{0}+\beta_{1}$ Ln(Assets $)_{i t}+\beta_{2}$ Debt to Assets $_{i t}+\beta_{3}$ Equity to Assets $_{i t}+$ Industry dummies + Year dummies $+v_{i t}-u_{i t}$

where Assets is a firm's total assets, Debt is firm's total interest-bearing liabilities and Equity is firm's total shareholding equity. Also, Industry dummies and Year dummies are utilised to control for industry fixed effects and year fixed effects, respectively. All the variables of Assets, Market value and Earnings before tax are transformed into their natural logarithm forms in order to reduce the skewness of the sample.

As presented in the methodology section, we follow Battese and Coelli (1995) model to estimate the effect of residual state ownership on the efficiency of privatized firms. In this study, Battese and Coelli (1995) model is specified as follows:

$$
\begin{aligned}
u_{i t}=\delta_{o} & +\delta_{1} \text { State ownership }_{i t} \\
& +\delta_{2} \text { Square of state ownership }_{i t} \\
& +\delta_{3} \text { Managerial ownership } \\
& +\delta_{4} \text { Board ownership }_{i t} \\
& +\delta_{5} \text { Domestic institutional ownership }_{i t} \\
& +\delta_{6} \text { Foreign institutional ownership }_{i t} \\
& \left.+\delta_{7} \text { Ln(Assets }\right)_{\text {it }} \\
& +\delta_{8} \text { Debt to Assets }
\end{aligned}
$$

$$
\begin{aligned}
& +\delta_{9} \text { Equity to Assets }_{\text {it }} \\
& + \text { Industry dummies } \\
& + \text { Year dummies }+ \text { wit }
\end{aligned}
$$

State ownership and the square of state ownership are incorporated into the model as we hypothesise the nonmonotonic relationship between residual state ownership and firm efficiency. Next, we also control for the effects of Managerial ownership, Board ownership, Domestic institutional ownership and Foreign institutional ownership since these factors were proved to have an impact on firm performance (Ang, Cole, \& Lin, 2000; Bhagat \& Bolton, 2008; Elyasiani \& Jia, 2010; McConnell \& Servaes, 1990). In addition, Ln(Assets), Debt to Assets, Equity to Assets, Industry dummies and Year dummies are added into the model since we expect that these variables may affect the level of inefficiency of privatized firms. As mentioned by Battese and Coelli (1995), the input variables in the stochastic frontier model may be included as the explanatory variables in the inefficiency model, provided that the inefficiency effects are stochastic.

\subsection{Data}

The data is collected from Thomson Reuters and firms'

\begin{tabular}{|c|c|c|c|c|c|c|}
\hline Variable & $\mathbf{N}$ & Mean & S.D. & Min & p50 & Max \\
\hline Market value (Billion VND) & 2,946 & 667.00 & $1,610.00$ & 7.74 & 173.00 & $15,800.00$ \\
\hline Ln of Market value & 2,945 & 25.98 & 1.50 & 22.77 & 25.87 & 30.34 \\
\hline Earnings before tax (Billion VND) & 2,946 & 87.90 & 211.00 & -92.80 & 26.20 & $2,290.00$ \\
\hline Ln of Earnings before tax & 2,829 & 24.06 & 1.55 & 19.84 & 24.07 & 28.53 \\
\hline Total assets (Billion VND) & 2,946 & $1,270.00$ & $2,550.00$ & 18.60 & 447.00 & $22,800.00$ \\
\hline Ln of Total assets & 2,945 & 26.89 & 1.38 & 23.64 & 26.83 & 30.75 \\
\hline Debt to Assets ratio & 2,976 & 0.22 & 0.18 & 0.00 & 0.19 & 0.69 \\
\hline Equity to Assets ratio & 2,945 & 0.49 & 0.21 & 0.09 & 0.46 & 0.94 \\
\hline State ownership (\%) & 3,006 & 41.70 & 19.16 & 5.00 & 49.00 & 96.72 \\
\hline Managerial ownership (\%) & 3,006 & 2.37 & 4.70 & 0.00 & 0.58 & 44.11 \\
\hline Board ownership (\%) & 3,006 & 4.68 & 7.69 & 0.00 & 1.42 & 93.52 \\
\hline Domestic institutional ownership (\%) & 3,006 & 5.27 & 11.37 & 0.00 & 0.00 & 79.58 \\
\hline Foreign institutional ownership (\%) & 3,006 & 2.60 & 7.23 & 0.00 & 0.00 & 51.69 \\
\hline
\end{tabular}
annual reports and financial statements of 439 non-financial partial-privatized firms listing on the Ho Chi Minh City Stock Exchange (HSX) and Hanoi Stock Exchange (HNX) over the period from 2007 to 2017 . We implement the natural logarithm transformation for variables of market value, earnings before tax and total assets. Also, we winsorise extreme $\left(1^{\text {st }}\right.$ and $\left.99^{\text {th }}\right)$ percentiles of the variables to remove the effects of outliers. Finally, we obtain the dataset as described in Table 1.

Table 1: Descriptive statistics of the variables

This table reports descriptive statistics of variables for the sample used in this study. 


\section{Results}

\subsection{Empirical Results}

The results from the market value frontier and profit frontier models are depicted in Panel A of Table 2. These results indicate that the size of a firm's assets is positively associated with the firm's market value and earnings before tax. The leverage ratio (i.e. debt to assets ratio) negatively affects the earnings before tax. Also, the amount of assets that are financed by owners' investments (i.e., equity to assets ratio) is demonstrated to have a positive impact on both the market value and profits of privatized firms. These results are consistent with previous studies conducted in the
Vietnamese context (Dang, Nguyen, \& Tran, 2020; Le \& Phan, 2017).

Table 3 provides some descriptive statistics of the efficiency of privatized firms. According to the results, privatized firms have an average market value efficiency of $64.74 \%$ and an average profit efficiency of $54.75 \%$. This result implies that, in comparison to the most efficient privatized firms, privatized firms are on average less efficient by 35.26 percentage points and 45.25 percentage points in terms of their market performance and profitability, respectively. In addition, the distribution of the profit efficiency is more dispersed than that of the market value efficiency since the standard deviation of the profit efficiency is larger than the standard deviation of the market value efficiency.

Table 2: Stochastic frontier analysis

\begin{tabular}{|c|c|c|}
\hline & $\begin{array}{l}\text { Market value frontier } \\
\text { (Ln of Market value) }\end{array}$ & $\begin{array}{c}\text { Profit frontier } \\
\text { (Ln of Earnings before tax) }\end{array}$ \\
\hline & Coef. & Coef. \\
\hline \multicolumn{3}{|l|}{ A. Frontier } \\
\hline Ln of Assets & $1.0690^{* * *}$ & $0.9950^{* * *}$ \\
\hline Debt to Assets & -0.3734 & $-1.0492^{* * *}$ \\
\hline Equity to Assets & $1.8584^{* \star *}$ & $1.2258^{\star * \star}$ \\
\hline Industry effects & Yes & Yes \\
\hline Year effects & Yes & Yes \\
\hline Constant & $-1.6608^{* * *}$ & $-2.7204^{\star * *}$ \\
\hline \multicolumn{3}{|l|}{ B. Inefficiency } \\
\hline State ownership & $-0.0232^{* * *}$ & $-0.0898^{* * *}$ \\
\hline Square of State ownership & $0.0002^{* * *}$ & $0.0008^{* * *}$ \\
\hline Managerial ownership & -0.0038 & $-0.0366^{*}$ \\
\hline Board ownership & $-0.0091^{*}$ & -0.0096 \\
\hline Domestic institutional ownership & -0.0038 & -0.0089 \\
\hline Foreign institutional ownership & -0.0196 & $-0.0611^{* * *}$ \\
\hline Ln of Assets & 0.0236 & -0.0968 \\
\hline Debt to Assets & -0.0707 & 0.8218 \\
\hline Equity to Assets & -0.5012 & -0.5142 \\
\hline Industry effects & Yes & Yes \\
\hline Year effects & Yes & Yes \\
\hline Constant & 0.4216 & -1.6746 \\
\hline \multicolumn{3}{|c|}{ C. Diagnostics for Stochastic Frontier Analysis } \\
\hline$\sigma_{u}$ & $0.3318^{*}$ & $1.4244^{* * *}$ \\
\hline$\sigma_{v}$ & $0.3535^{\star *}$ & $0.2656^{* * *}$ \\
\hline$\lambda=\left(\sigma_{u} / \sigma_{v}\right)$ & $0.9384^{* * *}$ & $5.3625^{* * *}$ \\
\hline Prob > chi2 & 0.0000 & 0.0000 \\
\hline Number of observations & 2,822 & 2,712 \\
\hline
\end{tabular}

This table reports the stochastic frontier analysis implemented in our study. Panel A presents the estimation of market value frontier and profit frontier. Panel B presents determinants of firm inefficiency. Panel C presents diagnostics of stochastic frontier analysis. ${ }^{*}$ denotes $p$-value $<$ $0.10 ;{ }^{* *}$ denotes $p$-value $<0.05$; and ${ }^{* * *}$ denotes $p$-value $<0.01$. 
Table 3: Descriptive statistics of efficiency of privatized firms

\begin{tabular}{|l|l|l|l|l|l|l|}
\hline \multicolumn{1}{|c|}{ Variable } & \multicolumn{1}{c|}{ Mean } & \multicolumn{1}{c|}{ p50 } & \multicolumn{1}{c|}{ S.D. } & \multicolumn{1}{c|}{ Min } & \multicolumn{1}{c|}{ Max } & \multicolumn{1}{c|}{ N } \\
\hline Market value efficiency & 0.6474 & 0.6938 & 0.2143 & 0.1053 & 0.9575 & 2822 \\
\hline Profit efficiency & 0.5475 & 0.5941 & 0.2643 & 0.0044 & 0.9655 & 2712 \\
\hline
\end{tabular}

This table reports descriptive statistics of market value efficiency and profit efficiency of privatized firms.

To provide a general view of the efficiency of privatized firms, we also graph the distribution of privatized firm efficiency in Figure 1. According to this figure, the efficiency of privatized firms has a left-skewed distribution. Additionally, the profit efficiency of privatized firms appears to have more variation than the market value efficiency.

The impact of ownership level on the inefficiency of privatized firms is also characterised in Panel B of Table 2. These results imply that state ownership has a non-monotonic impact on firm inefficiency since both state ownership and the square of state ownership have significant p-values. These findings are in agreement with our proposed Hypothesis.

To further assess the impact of different levels of residual state ownership on the efficiency of privatized firms, we calculate the marginal effect of residual state ownership on firm efficiency with all other variables held constant at their means. The marginal effect of residual state ownership is depicted in Figure 2.

According to the results, at a moderate level of state ownership, the relationship between state ownership and firm efficiency is positive. The figure reveals that when state ownership climbs from $0 \%$ to $50 \%$, the market value efficiency and profit efficiency increase from $47.74 \%$ to $68.26 \%$ and from $35.82 \%$ to $58.53 \%$, respectively. However, when state ownership is over $50 \%$, the net impact of state ownership is reversed and tends to negatively affect the efficiency of privatized firms. When state ownership increases from $50 \%$ to $100 \%$, the market value efficiency and profit efficiency of privatized firms drop significantly from $68.26 \%$ to $55.62 \%$ and from $58.53 \%$ to $38.37 \%$, respectively.

Furthermore, our results from the inefficiency model presented in Panel B of Table 2 show a negative impact of managerial ownership on the profit inefficiency of privatized firms. Board ownership is demonstrated to be negatively correlated with market value inefficiency. Foreign institutional ownership is negatively associated with the inefficiency of privatized firms in terms of profitability. These results are consistent with previous studies that support the positive roles of managerial ownership, board ownership and institutional ownership in upholding corporate governance practices and firm performance (Ang et al., 2000; Bhagat \& Bolton, 2008; Cornett, Marcus, Saunders, \& Tehranian, 2007; Elyasiani \& Jia, 2010; Lin \& Fu, 2017; McKnight \& Weir, 2009; Nguyen, Nguyen, Ngo, \& Nguyen, 2019; Singh \& Davidson III, 2003).

Panel C of Table 2 describes the diagnostics of the stochastic frontier model. The $\lambda \mathrm{s}$ of both the market value

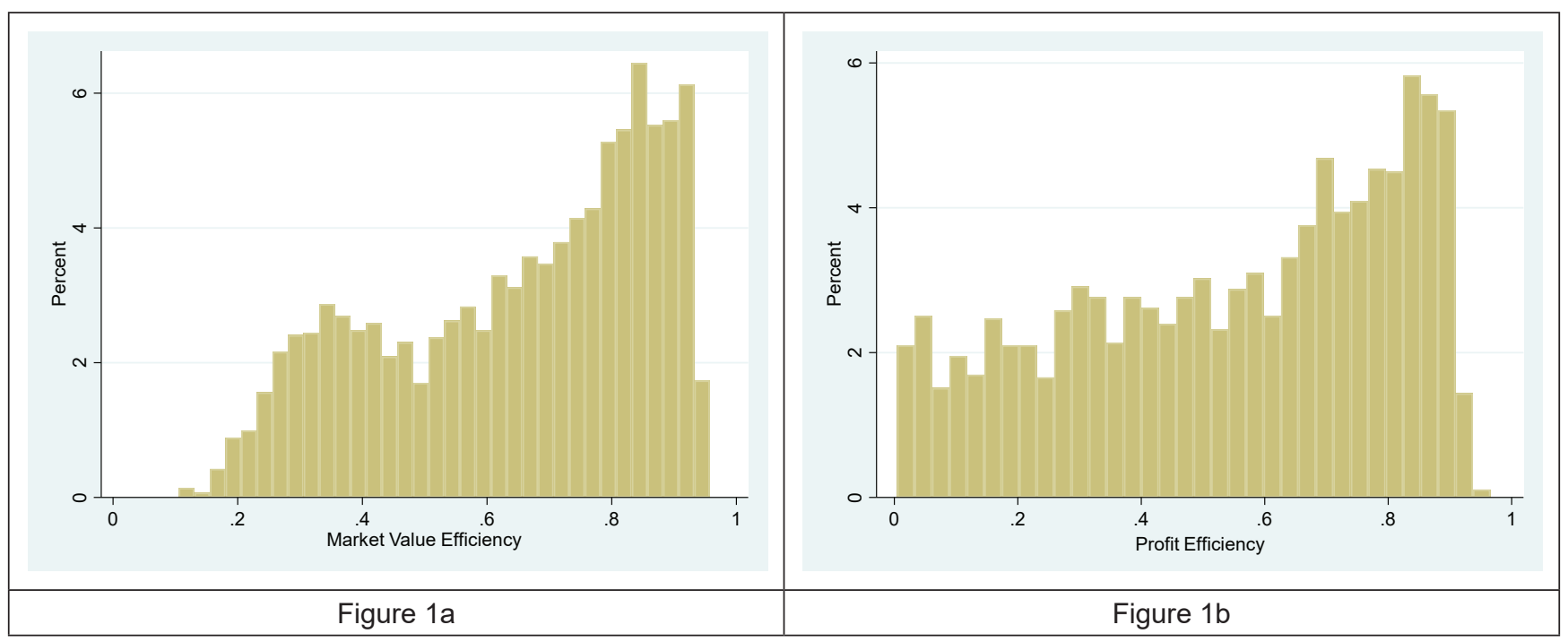

Figure 1: Histogram of privatized firms' efficiency

These figures present the distribution of market value efficiency and profit efficiency of privatized firms. 


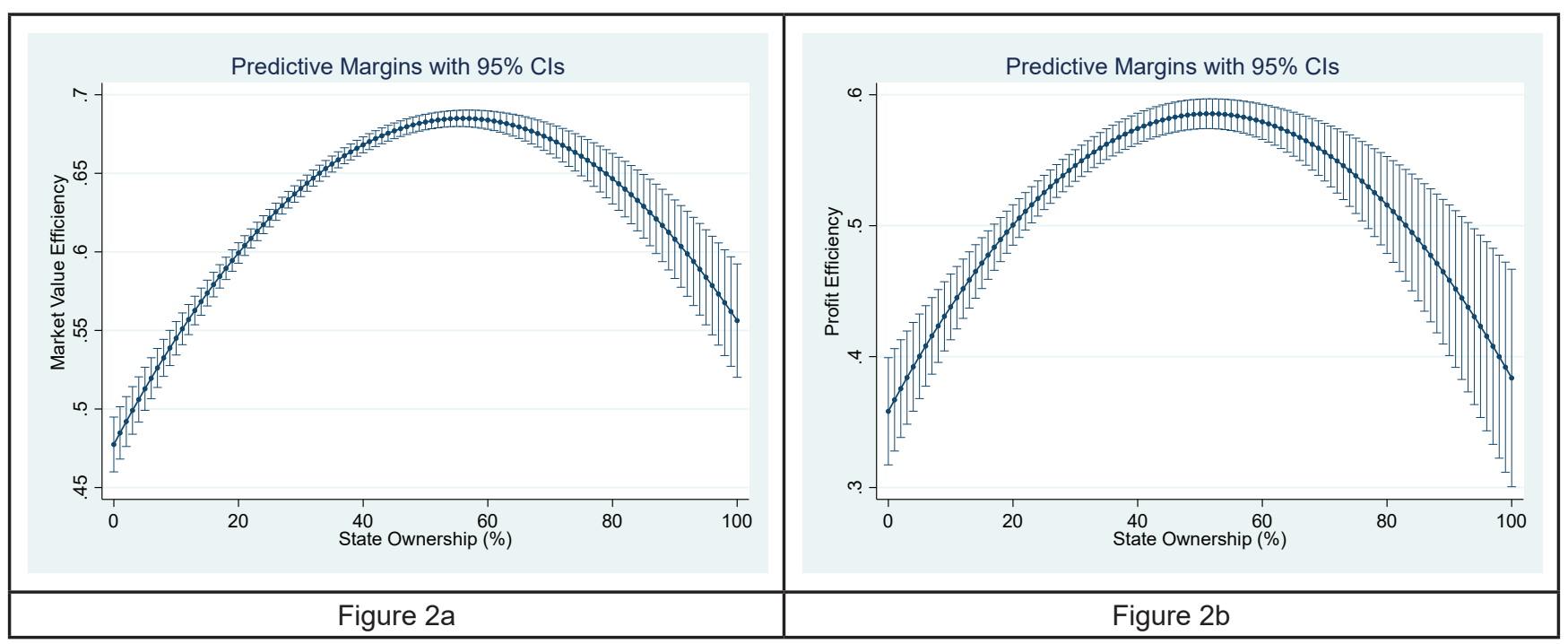

Figure 2: The marginal effect of state ownership on privatized firm efficiency

These figures present the marginal effect of state ownership on privatized firm's efficiency. The continuous lines correspond to the estimates, whereas the capped spikes correspond to the 95\% confidence intervals.

frontier model and the profit frontier model are significant. This result demonstrates that the deviations from the frontiers are mostly explained by the technical inefficiency rather than white noise or random effects.

\subsection{Robustness Test}

It is noted that our results may be subject to bias due to the endogeneity issue. Firstly, there could be the problem of causality since the government may decide the level of remaining ownership in accordance with the level of efficiency of privatized firms during the post-privatization period. Secondly, there could be some omitted variables that influence both state ownership and firm efficiency. Thus, the correlation between state ownership (i.e., endogenous variable) and the error term may exist. In this section, we aim to implement a two-stage least squares (2SLS) regression technique to deal with the endogeneity issue.

Following the idea of Boubakri et al. (2018), in which country-industry average of state ownership is used as an instrumental variable for state ownership, our study utilises industry-year average of residual state ownership as an instrumental variable when conducting 2SLS regression of privatized firm efficiency against state ownership. Industryyear average of state ownership could be a valid instrument since it is reasonable that the level of residual state ownership may be decided by the government according to state's industry preference; however, it is unlikely that industryyear average of state ownership may affect the efficiency of an individual privatized firm. The industry-year average of state ownership is not a weak instrument as the CraggDonald Wald F statistic, which is generated from our model, is 57.07 and larger than the critical value of 7.03 proposed by Stock and Yogo (2002).

Table 4 presents the results from our 2SLS regression model. These results are consistent with those presented in Sub-section 4.1 and support our Hypothesis indicating an inverted U-shaped relationship between residual state ownership and the efficiency of privatized firms. Also, from this model, it can be seen that managerial ownership, board ownership and institutional ownership are positively associated with the efficiency of privatized firms.

In addition, we graph the marginal effect of residual state ownership on both market value efficiency and profit efficiency in Figure 3. According to Figure 3, when state ownership increases from $0 \%$ to $50 \%$, the market value efficiency and profit efficiency climbs from $52.25 \%$ to $72.19 \%$ and from $37.44 \%$ to $59.98 \%$, respectively. However, when state ownership increases further from $50 \%$ to $100 \%$, the market value efficiency and profit efficiency tend to drop significantly from $72.19 \%$ to $60.67 \%$ and from $59.98 \%$ to $28.08 \%$, respectively. In comparison to the marginal effect which is generated from Figure 2, the marginal effect from Figure 3 shares some similarity in terms of the shape but have much wider confidence intervals.

\section{Discussion}

Results from our study indicate an inverted U-shaped relationship between residual state ownership and the efficiency of privatized firms. Specifically, a moderate 
Table 4: Two-stage least squares regressions of firm efficiency on state ownership

\begin{tabular}{|l|c|c|}
\hline \multirow{2}{*}{ Variable } & Market value efficiency & Profit efficiency \\
\cline { 2 - 3 } & Coef. & Coef. \\
\hline State ownership & $0.0071^{* * *}$ & $0.0099^{*}$ \\
\hline Square of State ownership & $-0.0001^{* * *}$ & $-0.0001^{*}$ \\
\hline Managerial ownership & $0.0037^{* * *}$ & $-0.0039^{* * *}$ \\
\hline Board ownership & $0.0020^{* * *}$ & 0.0001 \\
\hline Domestic institutional ownership & $0.0015^{* * *}$ & $0.0034^{* * *}$ \\
\hline Foreign institutional ownership & $0.0046^{* * *}$ & $0.0155^{* *}$ \\
\hline Ln of Assets & $0.0083^{* * *}$ & -0.0398 \\
\hline Debt to Assets & $0.1570^{* * *}$ & 0.0605 \\
\hline Equity to Assets & $-0.5217^{* * *}$ & Yes \\
\hline Industry effects & Yes & Yes \\
\hline Year effects & Yes & 0.4108 \\
\hline Constant & $0.4422^{* * *}$ & 0.0000 \\
\hline Prob > chi2 & 0.0000 & 2,712 \\
\hline Number of observations & 2,822 & \\
\hline
\end{tabular}

This table reports two-stage least squares regressions of privatized firm efficiency on state ownership and a set of control variables. * denotes $p$-value $<0.10$; ${ }^{* *}$ denotes $p$-value $<0.05$; and ${ }^{* * *}$ denotes $p$-value $<0.01$.

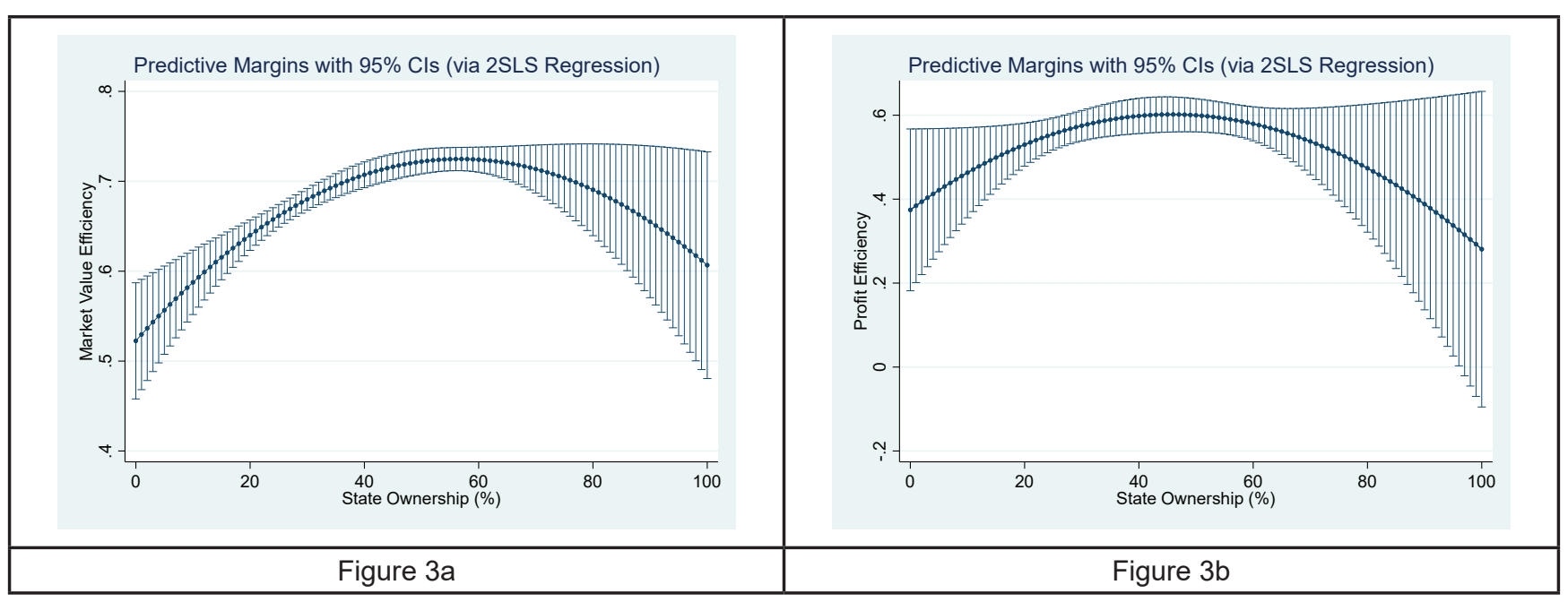

Figure 3: The marginal effect of state ownership on firm efficiency

These figures present the marginal effect of state ownership on partially privatized firm's efficiency. The continuous lines correspond to the estimates, whereas the capped spikes correspond to the $95 \%$ confidence intervals.

level of state ownership (less than $50 \%$ ) is beneficial to the efficiency of privatized firms in terms of both market performance and profitability. The positive effect of state ownership when residual state ownership is less than $50 \%$ could be explained by the minimal intervention from the government among privatized firms that the government does not impose dominant control. This could lead to better corporate governance practices, and managers of these firms are free to pursue pure value maximising strategies which are best beneficial to the interest of shareholders. In addition, the positive impact of state ownership could be explained by a potential "helping hand" of the government since the government still has an incentive to maximise the value of state capital among these privatized firms. 
The "helping hand" could be in a form of governmentrelated business opportunities, pre-determined output and/or input prices. Furthermore, in order to protect state capitals among these privatized firms, the government via its specialised monitoring agencies may act as a monitor to mitigate the wrongdoings of managers and expropriation activities of other block holders in these privatized firms. This "monitoring" effect could also enhance the efficiency of these firms.

In an opposite aspect, our study finds that when state ownership becomes dominant (more than 50\%), the positive effect of state ownership subsides and the relationship between residual state ownership and privatized firm efficiency turns out to be negative. One most notable explanation for the negative effect of state ownership is that most of privatized firms with dominant state ownership are potentially vulnerable to governmental intervention. When state holds dominant control of over $50 \%$, it may actively control the operations of privatized firms and consequently, may divert firm resources to pursue non-economic objectives such as invest in less profitable social or non-economic projects which result in less economic efficiency. Also, since the state ownership is dominant, other shareholders do not hold a counter-balanced control to oppose governmental intervention and enforce their monitoring role. Moreover, these privatized firms may experience soft budget constraint issue which potentially weakens incentives of managers to uphold firm efficiency. In addition, weak incentives of managers are possibly signified as takeover threats may not be prevalent to managers of privatized firms with large residual state ownership.

From our findings, it could be implied that the relinquishment of the dominant control of the state via privatization in general can potentially promote the efficiency of state-owned enterprises. However, the impact of state ownership is not linearly negative. At the pivotal point of $50 \%$, further reduction of state ownership tends to be detrimental to the efficiency of privatized firms.

These findings are consistent with Le et al. (2019) and Hoang et al. (2017) who found an inverted U-shaped relationship between state ownership and firm performance in the context Vietnam. Similarly, in the regional context, Boubakri et al. (2018) found the inverted U-shaped association between state ownership and firm performance across 9 East Asian economies.

This is also in agreement with previous studies that suggest that, in countries associated with weak corporate governance system and limited protection of minority shareholders, privatization may not bring universally positive effects (Dharwadkar, George, \& Brandes, 2000; Megginson \& Netter, 2001; Shleifer \& Vishny, 1997). In these contexts, the further reduction of state ownership might lead to the rise of the agency problem of managerial control, which may outweigh the reduction of political control during the post-privatization period. Therefore, in some transitional economies associated with weak rule of law and corporate governance system, the partial and gradual privatization might be a temporarily optimal strategy. In this optimal circumstance, state ownership implements a "monitoring" role to prevent both the wrongdoing of managers and the expropriation behavior of other block holders; however, the state's holdings are not large enough to divert firms' resources to pursue political objectives. Moreover, this creates an opportunity for both state and other shareholders to balance their control to simultaneously supervise the management activities of privatized firms and maximise the efficiency of these firms during post-privatization period.

\section{Conclusion}

In conclusion, our study suggests that state ownership should not be considered as a pure source of agency problems. Indeed, the impact of residual state ownership on privatized firm efficiency is non-monotonic at least in the context of transitional economy of Vietnam. A moderate level of residual state ownership might be beneficial to privatized firm efficiency whereas too much state ownership is detrimental to the efficiency of privatized firms. This finding is not against the appropriateness of agency theory, but shed some further light on the agency problem of state ownership in the specific context of Vietnam. It also proposes scientific evidence which might be used as a suggestive guidance for the privatization policy of Vietnamese government.

\section{References}

Aigner,D.,Lovell,C.,\&Schmidt,P.(1977).Formulationandestimation of stochastic frontier production function models. Journal of Econometrics, 6(1), 21-37. Retrieved from https://EconPapers. repec.org/RePEc:eee:econom:v:6:y:1977:i:1:p:21-37

Ang, J. S., Cole, R. A., \& Lin, J. W. (2000). Agency costs and ownership structure. Journal of Finance, 55(1), 81-106. doi:10.1111/0022-1082.00201

Battese, G., \& Coelli, T. (1995). A model for technical inefficiency effects in a stochastic frontier production function for panel data. Empirical Economics, 20(2), 325-332. doi:10.1007/ BF01205442

Bennedsen, M. (2000). Political ownership. Journal of Public Economics, 76(3), 559-581. doi:10.1016/S00472727(99)00096-1

Bhagat, S., \& Bolton, B. (2008). Corporate governance and firm performance. Journal of Corporate Finance, 14(3), 257-273. doi:https://doi.org/10.1016/j.jcorpfin.2008.03.006 
Boubakri, N., Cosset, J.-C., \& Guedhami, O. (2005). Postprivatization corporate governance: The role of ownership structure and investor protection. Journal of Financial Economics, 76(2), 369-399. doi:10.1016/j.jfineco.2004.05.003

Boubakri, N., El Ghoul, S., Guedhami, O., \& Megginson, W. L. (2018). The market value of government ownership. Journal of Corporate Finance, 50, 44-65. doi:10.1016/j. jcorpfin.2017.12.026

Boycko, M., Shleifer, A., \& Vishny, R. W. (1996). A theory of privatisation. The Economic Journal, 106(435), 309-319. doi: $10.2307 / 2235248$

Chang, H.-J. (2007). State-Owned Enterprise Reform. Retrieved from https://EconPapers.repec.org/RePEc:une:pnotes:4

Coelli, T., Rao, D. S., O'Donnell, C., \& Battese, G. (2005). An Introduction to Efficiency and Productivity Analysis.

Cornett, M. M., Marcus, A. J., Saunders, A., \& Tehranian, H. (2007). The impact of institutional ownership on corporate operating performance. Journal of Banking and Finance, 31(6), 1771-1794. doi:10.1016/j.jbankfin.2006.08.006

Dang, H. N., Nguyen, T. T. C., \& Tran, D. M. (2020). The Impact of Earnings Quality on Firm Value: The Case of Vietnam. Journal of Asian Finance, Economics and Business, 7(3), 63-72. https:// doi.org/10.13106/jafeb.2020.vol7.no3.63

Dharwadkar, R., George, G., \& Brandes, P. (2000). Privatization in emerging economies: An agency theory perspective. The Academy of Management Review, 25, 650-669. doi: $10.2307 / 259316$

Elyasiani, E., \& Jia, J. (2010). Distribution of institutional ownership and corporate firm performance. Journal of Banking and Finance, 34(3), 606-620. doi:10.1016/j.jbankfin.2009.08.018

Greene, W. H. (2012). The econometric approach to efficiency analysis,. In The Measurement of Productive Efficiency and Productivity Growth. New York, NY: Oxford University Press.

Haider, Z. A., Liu, M., Wang, Y., \& Zhang, Y. (2018). Government ownership, financial constraint, corruption, and corporate performance: International evidence. Journal of International Financial Markets, Institutions \& Money, 53, 76-93. doi:10.1016/j.intfin.2017.09.012

Hoang, L. T., Nguyen, C. C., \& Hu, B. (2017). Ownership structure and firm performance improvement: Does it matter in the Vietnamese stock market? Economic Papers: A Journal of Applied Economics and Policy, 36(4), 416-428. doi:10.1111/1759-3441.12185

Jensen, M. C., \& Meckling, W. H. (1976). Theory of the firm: managerial behavior, agency costs and ownership structure.

Kornai, J. (1986). The soft budget constraint. Kyklos, 39(1), 3-30. doi:10.1111/j.1467-6435.1986.tb01252.x

Kumbhakar, S., Ortega-Argilés, R., Potters, L., Vivarelli, M., \& Voigt, P. (2012). Corporate R\&D and firm efficiency: evidence from Europe's top R\&D investors. Journal of Productivity Analysis, 37(2), 125-140. doi:10.1007/s11123-011-0223-5
Laffont, J., \& Tirole, J. (1991). Privatization and incentives. Journal of Law, Economics, \& Organization, 7, 84-105.

Le, M. D., Pieri, F., \& Zaninotto, E. (2019). From central planning towards a market economy: The role of ownership and competition in Vietnamese firms' productivity. Journal of Comparative Economics, 47(3), 693-716. doi:https://doi. org/10.1016/j.jce.2019.04.002

Le, T. P. V., \& Phan, T. B. N. (2017). Capital structure and firm performance: Empirical evidence from a small transition country. Research in International Business and Finance, 42, 710-726. doi:10.1016/j.ribaf.2017.07.012

Li, K., Yue, H., \& Zhao, L. (2009). Ownership, institutions, and capital structure: Evidence from China. Journal of Comparative Economics, 37(3), 471-490. doi:10.1016/j.jce.2009.07.001

Lin, Y. R., \& Fu, X. M. (2017). Does institutional ownership influence firm performance? Evidence from China. International Review of Economics \& Finance, 49, 17-57. doi:10.1016/j.iref.2017.01.021

Liu, N., Wang, L., Zhang, M., \& Zhang, W. (2012). Government intervention and executive compensation contracts of stateowned enterprises: empirical evidence from China. Journal of Chinese Economic and Business Studies, 10(4), 391-411. doi:1 0.1080/14765284.2012.724983

Loc, T. D., Lanjouw, G., \& Lensink, R. (2006). The impact of privatization on firm performance in a transition economy. Economics of Transition, 14(2), 349-389. doi:10.1111/j.14680351.2006.00251.x

Manzur Quader, S., \& Dietrich, M. (2014). Corporate efficiency in the UK: a stochastic frontier analysis. International Journal of Productivity and Performance Management, 63(8), 991-1011. doi:10.1108/IJPPM-07-2013-0125

McConnell, J. J., \& Servaes, H. (1990). Additional evidence on equity ownership and corporate value. Journal of Financial Economics, 27(2), 595-612. doi:10.1016/0304405X(90)90069-C

McKnight, P. J., \& Weir, C. (2009). Agency costs, corporate governance mechanisms and ownership structure in large UK publicly quoted companies: A panel data analysis. Quarterly Review of Economics and Finance, 49(2), 139-158. doi:10.1016/j.qref.2007.09.008

Megginson, W. L., Nash, R. C., \& Randenborgh, M. (1994). The financial and operating performance of newly privatized firms: An international empirical analysis. Journal of Finance, 49(2), 403-452. doi:10.1111/j.1540-6261.1994.tb05147.x

Megginson, W. L., \& Netter, J. M. (2001). From state to market: A survey of empirical studies on privatization. Journal of Economic Literature, 39(2), 321-389. doi:10.1257/jel.39.2.321

Mohamed, S. (2020). Resource Use Efficiency of Electricity Sector in the Maldives. Journal of Asian Finance, Economics and Business, 7(1), 111-121. https://doi.org/10.13106/jafeb.2020. vol7.no1.111 
Ngo, M. T., Nonneman, W., \& Jorissen, A. (2014). Government ownership and firm performance: The case of Vietnam. International Journal of Economics and Financial Issues, 4(3), 628-650.

Ngo, M. T., Nonneman, W., \& Jorissen, A. (2015). Privatization of Vietnamese firms and its effects on firm performance. Asian Economic and Financial Review, 5(2), 202-217. doi:10.18488/ journal.aefr/2015.5.2/102.2.202.217

Nguyen, G. X., \& Swanson, P. E. (2009). Firm characteristics, relative efficiency, and equity returns. Journal of Financial and Quantitative Analysis, 44(1), 213-236. doi:10.1017/ S0022109009090012

Nguyen, P. A., Nguyen, A. H., Ngo, T. P., \& Nguyen, P. V. (2019). The Relationship between Productivity and Firm's Performance: Evidence from Listed Firms in Vietnam Stock Exchange. Journal of Asian Finance, Economics and Business, 6(3), 131-140. https://doi.org/10.13106/jafeb.2019.vol6. no3.131

Phung, D. N., \& Mishra, A. V. (2016). Ownership structure and firm performance: Evidence from Vietnamese listed firms. Australian Economic Papers, 55(1), 63-98. doi:10.1111/14678454.12056

Sheshinski, E., \& López-Calva, L. (2003). Privatization and its benefits: Theory and evidence. CESifo Economic Studies, 49(3), 429-460. doi:10.1093/cesifo/49.3.429

Shleifer, A., \& Vishny, R. W. (1997). A survey of corporate governance (Vol. 52, pp. 737-783).
Shleifer, A., \& Vishny, R. W. (1998). The grabbing hand : government pathologies and their cures. Cambridge, MA: Harvard University Press.

Singh, M., \& Davidson III, W. N. (2003). Agency costs, ownership structure and corporate governance mechanisms. Journal of Banking and Finance, 27(5), 793-816. doi:10.1016/S03784266(01)00260-6

Souza, J., Megginson, W., \& Nash, R. (2005). Effect of institutional and firm-specific characteristics on post-privatization performance: Evidence from developed countries. Journal of Corporate Finance, 11(5), 747-766. doi:10.1016/j. jcorpfin.2004.12.001

Souza, J., \& Megginson, W. L. (1999). The financial and operating performance of privatized firms during the 1990s. Journal of Finance, 54(4), 1397-1438. doi:10.1111/0022-1082.00150

Stock, J. H., \& Yogo, M. (2002). Testing for weak instruments in linear IV regression.

Tian, L., \& Estrin, S. (2008). Retained state shareholding in Chinese PLCs: Does government ownership always reduce corporate value? Journal of Comparative Economics, 36(1), 74-89. doi:10.1016/j.jce.2007.10.003

Vo, T. Q., Swierczek, F., \& Nguyen, D. K. (2013). Corporate performance of privatized firms in Vietnam. Journal of Applied Business Research, 29(5), 1437. doi:10.19030/jabr.v29i5.8025 
